\title{
Jenis-Jenis Bambu Dataran Tinggi di Sempadan Sungai Trengwilis Taman Nasional Gunung Rinjani Lombok
}

\author{
Dewi Fatmalasari ${ }^{1}$, Tri Mulyaningsih ${ }^{* 2}$, Evy Aryanti ${ }^{3}$ \\ *e-mail: trimulya@unram.ac.id \\ ${ }^{I}$ Program Studi Biologi, Fakultas Matematika dan Ilmu Pengetahuan Alam \\ Universitas Mataram, Mataram, NTB
}

\begin{abstract}
Indonesia has 176 species and 24 genera of bamboos, around $11.5 \%$ of the total bamboo species in the world. In Lombok, there were found 6 genera, 15 species and 8 varieties. Bamboo has an important role on the river banks, it can prevent erosion of the river cliffs. The purpose of this study was to identify the species of highland bamboos, at the border of the Trengwilis river, Rinjani Mount National Park, Lombok. This research was conducted by descriptive explorative method, on July - April 2019. The Collecing data was used line sampling methode, with exploring the river border, 50 meters from the left and right edges of riverbed. Data collection in the field was carried out by recording 72 bamboo characters. The results were found seven species of bamboo which were included in five genera, e.g. Bambusa vulgaris Schard., Schizotachyum sp., Dendrocalamus sp. Dendrocalamus asper (Schult) Backer, Gigantochloa sp., Gigantochloa atter (Hassk.) Kurz., that were found at an attitude $623 \mathrm{~m}-660 \mathrm{~m}$ asl.; Gigantochloa apus (Schult.) Kurz. that grew as long as the Trengwilis riverbed at around atitude $623 \mathrm{~m}-729 \mathrm{~m}$ asl.
\end{abstract}

Keywords: Bamboo, Trengwilis river, Rinjani Mount Nasional Park, Lombok, Indonesia.

\begin{abstract}
ABSTRAK
Indonesia memiliki 176 jenis dan 24 marga bambu sekitar $11.5 \%$ dari jumlah jenis bambu di dunia. Marga bambu telah ditemukan di Pulau Lombok ada 6 marga, 15 spesies dan 8 varietas. Bambu mempunyai peran penting di pinggiran sungai, karena dapat mencegah erosi tebing sungai. Tujuan penelitian ini adalah untuk mengidentifikasi jenis-jenis bambu dataran tinggi, di sempadan sungai Trengwilis Taman Nasional Gunung Rinjani Lombok. Penelitian ini dilaksanakan pada bulan Juli - April 2019, penelitian ini bersifat deskriptif eksploratif, pengumpulan sampel menggunakan metode jelajah, yaitu menjelajahi sempadan sungai, 50-meter dari tepi kiri dan kanan palung sungai Trengwilis. Pengumpulan data di lapangan dilakukan dengan mencatat sebanyak 72 karakter bambu. Hasil penelitian didapatkan tujuh jenis bambu yang termasuk ke dalam lima genus yaitu Bambusa vulgaris Schard., Schizotachyum sp., Dendrocalamus sp., Dendrocalamus asper (Schult) Backer, Gigantochloa sp. dan Gigantochloa atter (Hassk.) Kurz. yang diketemukan tumbuh pada ketinggian 623m-660m dpl; Gigantochloa apus (Schult.) Kurz. dapat tumbuh di sepanjang sempadan sungai Trengwilis pada ketinggian 623m-729m dpl.
\end{abstract}

Kata Kunci: Bambu, Sungai Trengwilis, Taman Nasional Gunung Rinjani, Lombok, Indonesia. 


\section{PENDAHULUAN}

\begin{abstract}
Bambu memiliki peranan yang sangat penting dalam kehidupan masyarakat salah satunya yaitu sebagai bahan bangunan, kerajinan dan sebagai bahan pangan, di Bali bambu tali ( $G$. apus) dimanfaatkan dalam pembuatan sokasi (sejenis bakul tertutup khas ala Bali) dan gedeg yang khas dan kaya akan variasi dibuat dari bambu buluh $S$. lima,
\end{abstract}

$S$. zollingeri dan $S$. castaneum (Bagus, 2005). Di desa Cijedil, Jawa Barat, batang bambu gombong dimanfaatkan dalam pembuatan ajir (patok untuk menanam sayur), sedangkan daunnya dimanfaatkan sebagai bahan bakar perapian (Hanafi, et al., 2017). Selain itu bambu juga dimanfaatkan dalam pembuatan alat musik angklung, industri mebel, bilik dan kerajinan tangan yang berasal dari jenis bambu hitam ( $D$. atroviolaceae) (Cundaningsih, et al., 2015). Taman Nanonal Alas purwo, bambu dimanfaatkan dalam bidang perikanan sebagai alat penangkap ikan, konstruksi rumah, bahan baku perkakas rumah tangga dan bahan makanan (Mayasari \& Suryawan, 2012).

Pemanfaatan bambu di Lombok diantaranya sebagai bahan bangunan seperti pembuatan pagar sebagai dinding rumah, tiang rumah, kios-kios darurat dan pengganti pipa saluran air yaitu dari jenis treng petung ( $D$. asper) dan treng dendeng (B. vulgaris). Alat kerajinan seperti anyaman, pembuatan bakul (keraro), kong (kurungan ayam), kecapil, dan tas panjang terbuat dari jenis treng tali ( $G$. apus), pembuatan seruling dan pancing dari genus ( $S$. jaculan). Rebung bambu dapat dimanfaatkan sebagai bahan pangan yang dapat diolah sebagai lauk, keripik dan abon.

Menurut Peneng (2005), ada lima jenis bambu yang berpotensi sebagai alat kerajinan rumah tangga dan konstruksi bangunan yaitu treng tutul (B. maculata), treng tali (G. apus), treng galah ( $G$. atter), treng petung ( $D$. asper), dan treng greng (B. blumeana).

Jenis bambu di dunia diperkirakan berjumlah 1500 jenis, jumlah bambu di Indonesia hanya $11,5 \%$ dari jumlah bambu dunia yaitu sekitar 176 jenis, 24 marga (Clark et al., 2015; Ervianti et al., 2019; Rijaya \& Fitmawati, 2019). Pulau Lombok memiliki 6 marga bambu (Bambusa, Dendrocalamus, Gigantochloa, Guadua, Schizotachyum dan Thyrsostachys,) yang meliputi 15 spesies (Guadua angustifolia, Thyrsostachys siamensis, S. jaculans, S. brachyladum, Schizotachyum spp. D. asper, G. atter, G. apus, B. maculata, B. multiplex, $B$. blumeana, B. vulgaris, B. glaucophyla, $B$. ventricosa, $B$. albustiata) dan 8 varietas:

$B$. vulgaris, var. vitata (treng aur gading besar), B. vulgaris var. green (treng aur hijau), B. vulgaris var. yellow (treng aur gading kecil), S. brachyladum var. green (treng tamblang hijau), S. brachyladum var. yellow (treng tamblang gading), $B$. multiplex var. green (treng cina hijau), B.multiplex var. yellow (treng cina gading), dan G. apus var. yellow (treng tali gading) (Putri, et al., 2016; Huzaemah, et al., 2017; Mentari, et al., 2018; Munawarah, 2017; Peneng. et al., 2005).

Resort Joben atau Otak Kokok merupakan salah satu tempat wisata yang begitu menarik perhatian para wisatawan yang terletak di antara 3 Dusun yaitu Dusun Pesanggrahan, Perian dan Taer-aer kecamatan Motong gading, karena kesuburan dan keindahan alamnya yang masih tergolong alami, salah satunya dengan keberadaan sungai Trengwilllis, yang terletak di antara dua Dusun yaitu Dusun Srijata dan Dusun Taer-aer.

Sungai Trengwilis merupakan satu-satunya Sungai yang menjadi daya tarik para wisatawan dari dalam maupun dari luar karena memiliki keindahan tersendiri dengan keberadaan air terjun 
yang indah dan airnya yang jernih dan memiliki sumber mata air. Tanahnya berpasir, topografi ada yang landai, sangat terjal dan curam, ditumbuhi oleh berbagai jenis tumbuhan seperti semak, liana dan pohon-pohonan salah satunya yaitu bambu.

Bambu yang tumbuh memiliki keanekaragaman jenis yang lebih spesifik, memiliki sistem perakaran yang rapat, luas dan kuat sehingga mampu menjaga partikel tanah dengan baik dan dapat mencegah terjadinya longsor terhadap tebing sungai yang terjal. Namun penebangan bambu di tebing sungai Trengwilis dilakukan secara illegal dan sangat intensif oleh masyarakat, terutama digunakan untuk memperbaiki saluran air yang berada di sepanjang aliran sungai tersebut, sehingga pertumbuhan populasi bambu sangat lambat dan hampir punah.

Berdasarkan uraian di atas maka perlu dilakukan penelitian keanekaragaman jenis bambu yang berada di Taman Nasional Gunung Rinjani, salah satunya di sempadan sungai Trengwilis, sebelum populasi bambu tersebut mengalami kepunahan. Oleh sebab itu pentingya penelitian ini dilakukan yang bertujuan untuk mengetahui jenis-jenis bambu dataran tinggi di sempadan sungai Trengwillis Taman Nasional Gunung Rinjani, Lombok. Penelitian ini diharapkan dapat digunakan sebagai dasar untuk memilih jenis-jenis bambu yang dapat digunakan untuk mengkoservasi tebing sungai di dataran tinggi.

\section{BAHAN DAN METODE}

Penelitian ini bersifat deskriptif eksplorasif, kegiatan penelitian ini dilaksanakan pada bulan Juli 2018 hingga bulan Februari 2019. Tempat pengambilan sampel di sepanjang sempadan sungai Trengwilis $(4,85 \mathrm{~km})$, Resort Joben, Taman Nasional Gunung
Rinjani Lombok. Identifikasi dilakukan di Laboratorium Penelitian Kajian Gaharu Fakultas Matematika dan Ilmu Pengetahuan Alam Universitas Mataram.

Alat-alat yang berkaitan dalam pembuatan herbarium seperti sasak, meteran, parang, buku identifikasi, jangka sorong, kantong plastik, GPS, alat tulis dan thermohygro, serta yang berkaitan dengan dokumentasi yaitu kamera dan handpone (HP).

Bahan-bahan yang digunakan dalam pembuatan herbarium seperti kertas koran, benang kasur, karung, alkohol 70\%, label gantung, selotif, kertas gambar CD (A3), tali rapia dan kertas label.

Pengambilan sampel dilakukan dengan menggunakan metode jelajah, yakni kolektor menjelajahi Sempadan Sungai Trengwilis Resort Joben Taman Nasional Gunung Rinjani Lombok untuk mengoleksi semua jenis bambu, dengan lebar ke samping 50 meter dari tepi kiri dan kanan palung sungai berdasarkan pada Peraturan Pemerintah Republik Indonesia Nomor 38 Tahun 2011 mengenai Sungai (Huzaemah, et al., 2016).

Sampel yang dikoleksi berupa: rebung, percabangan, daun, pelepah batang, dan bunga tidak dijumpai karena bambu yang tumbuh sangat itensif yang disebabkan penebangan secara liar. Data tersusun atas 3 yaitu data lapangan, data herbarium, dan data fisik. Data lapangan diantaranya seperti tinggi pohon, luas perakaran, tipe perakaran, arah pertumbuhan rebung, bentuk kanopi, bentuk percabangan, tinggi percabangan, posisi daun pelepah batang dan warna daun. Data herbarium seperti rebung, pelepah batang, percabangan, dan daun serta data fisik seperti titik koordinat, ketinggian, suhu, dan kelembaban. Data masing-masing jenis bambu dicatat dalam tabel karakter yang telah disediakan berisi (72 karakter), diambil tiga bagian dari organ bambu yang 
ditemukan yaitu bagian rebung, daun, percabangan, pelepah batang dan organ reproduksi jika ada.

Data yang terkumpul dilakukan identifikasi lebih lanjut untuk menemukan nama jenisnya menggunakan pustaka yang relevan seperti: Dieter, 2018; dan URL http://www.plantlist.org dan http://www.kew.grass.org, Simpson, 2006.

Analisis data menggunakan analisis deskriptif. Hasil analisis data disajikan dalam bentuk, kunci identifikasi, deskripsi, gambar dan peta persebaran.

\section{HASIL DAN PEMBAHASAN}

\section{Kunci Identifikasi Jenis-Jenis Bambu di sempadan sungai Trengwilis Taman Nasinonal Gunung Rinjani, Lombok.}

1. a. Permukaan ruas batang gundul, licin, dan mengkilat... Bambusa vulgaris

b. Permukaan ruas batang tidak gundul licin, dan mengkilat ........ 2

2. a. Warna permukaan ruas batang hijau kekuningan, diameter ruas batang kurang dari $3 \mathrm{~cm}$ Schizotachyum sp.

b. Warna permukaan ruas batang hijau, diameter ruas batang lebih dari $3 \mathrm{~cm}$

3. a. Bentuk daun pelepah batang lanset, tangkai daun berbulu balig halus bening, permukaan daun adaksial gundul 4

b. Bentuk daun pelepah batang bulat telur, tangkai daun gundul, permukaan daun adaksial berbulu balig halus putih

4. a. Akar udara tumbuh lebih dari buku ke-3, bentuk pelepah batang segitiga sama kaki memanjang, permukaan sisi luar pelepah batang berbulu bersusuhan krem, berbulu balig halus hitam, menggimbal sangat halus putih tersebar merata, bentuk telinga pelepah batang appendik aculate pirang.... Dendocalamus sp.

b. Akar udara tumbuh pada buku ke-3 bentuk pelepah batang segitiga sama kaki melebar, permukaan sisi luar pelepah batang berbulu bersusuhan coklat tersebar merata jarang, pelepah batang tidak memiliki telinga ......Dendrocalamus asper

5. a. Pelepah batang mendelta, margo (pinggiran) rata kecuali di bagian ujung menjenggot hitam, tidak mudah luruh, panjang pelepah daun lebih dari $12 \mathrm{~cm}$ ................Gigantochloa apus

b. Pelepah batang segitiga sama kaki melebar, margo rata, mudah luruh, panjang pelepah daun kurang dari 12 $\mathrm{cm}$. 6

6. a. Margo lidah pelepah batang bergerigi jumlah tulang daun lebih dari 6 helai Gigantocloa atter

b. Margo lidah pelepah batang rata, jumlah tulang daun kurang dari 6 helai

Gigantochloa sp.

\section{Deskripsi Jenis-Jenis Bambu di Sempadan Sungai Trengwilis Resort Joben Taman Nasional Gunung Rinjani Lombok.}

\section{Dendrocalams asper (Schult.)} Backer. Nutt. PI. Ned. Ind. Ed.2, 1: 3011927.

Arah pertumbuhan rebung searah jarum jam, rebung kerucut, pelepah tersusun sangat rapat, warna coklat kekuningan, bulu bersusuhan warna coklat kehitaman tebal dan rapat. Perakaran luas $16 \mathrm{~m}^{2}$, tipe simpodial; akar udara mucul hingga buku ke 2-3. 
Kanopi membulat. Ruas batang panjang $\times$ diameter $=27 \mathrm{~cm}-40 \mathrm{~cm} \times 5,5 \mathrm{~cm}-7,3 \mathrm{~cm}$, warna hijau tua keabu-abuan, permukaan berusuhan (strigose) coklat muda, tebal di ujung buku batang. Buku-buku batang, panjang $\times$ diameter $=1 \mathrm{~cm}-2 \mathrm{~cm} \times 6,6 \mathrm{~cm}-$ $7,8 \mathrm{~cm}$; memiliki 2 cincin coklat muda di atas dan di bawah buku batang. Pelepah batang segitiga sama kaki melebar; tinggi $\times$ alas $=13,5 \mathrm{~cm}-26 \mathrm{~cm} \times 5,2 \mathrm{~cm}-23,5 \mathrm{~cm}$, mudah luruh, sisi luar beralur, sejajar, berusuhan coklat tersebar merata jarang, sisi dalam beralur, gundul, licin mengkilat; pinggiran lidah pelepah mengutuh, tinggi lidah $=0,1 \mathrm{~cm}-0,2 \mathrm{~cm}$. Daun pelepah batang jorong, tinggi $\times$ alas $=3,5 \mathrm{~cm}-7,6 \mathrm{~cm} \times 0,9 \mathrm{~cm}-3,2 \mathrm{~cm}$, terlekuk balik, sisi luar beralur, berssusuhan pirang, sisi luar beralur, berbulu balig halus, pirang, sangat jarang di bagian basal; pinggiran menggeregaji. Percabangan 2 cabang dominan (two dominant branches at node), jumlah cabang mencapai 22/ buku batang, percabangan mulai dari buku ke 2-3 pada ketinggian $15 \mathrm{~cm}-37 \mathrm{~cm}$. Pelepah daun

melonjong, tinggi $\times$ alas $=8,3-10,1 \mathrm{~cm}$ $\times 0,75-1 \mathrm{~cm}$, sisi luar beralur, berbulu balig halus bening (transparan) di ujung, sisi dalam beralur, gundul, licin mengkilat; margo mengutuh, telinga pelepah daun appendik gundul. Tangkai daun berbulu balig halus putih jarang, panjang $=0,1 \mathrm{~cm}-0,6 \mathrm{~cm}$. Helaian daun melonjong, panjang $\times$ lebar $=17 \mathrm{~cm}-$ $33 \mathrm{~cm} \times 2 \mathrm{~cm}-4,5 \mathrm{~cm}$, hijau tua, bagian abaksial, berbulu balig halus bening; bagian adaksial beralur, gundul, pertulangan daun menonjol kearah adaksial; jumlah tulang daun lateral (vena) 8 helai; pangkal daun tidak simetris; ujung daun menjarum; pinggiran daun menggergaji.

Distribusi: Lombok Timur, Montong Gading, desa Perian, dusun Srijata, sungai Trengwillis TNGR. Nama lokal: Tereng Petung (Sasak Srijata). Habitat: tumbuh di tanah berpasir, pada tebing sungai, suhu $31^{\circ} \mathrm{C}$, kelembaban $94 \%$, ketinggian $631 \mathrm{~m}-652 \mathrm{~m} \mathrm{dpl}$.

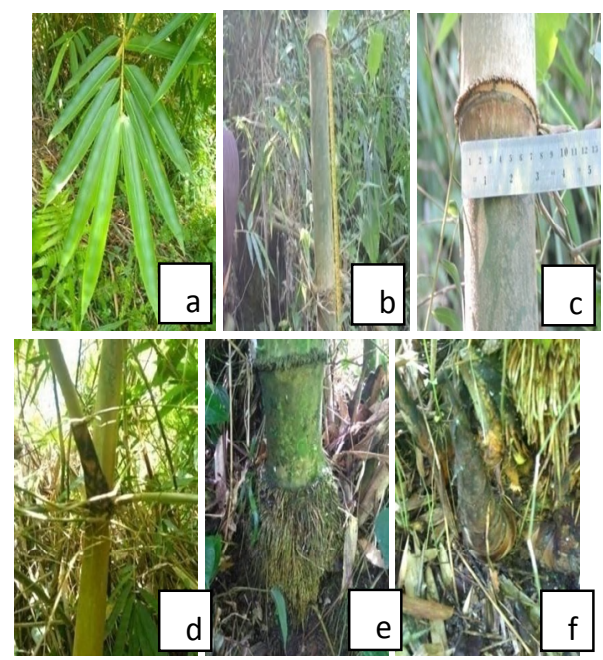

Gambar 1. D. asper: (a). daun, (b). batang, (c). buku batang, (d). percabangan, (e). perakaran, (f). rebung.

\section{Dendrocalamus sp.}

Arah pertumbuhan rebung se arah jarum jam. Rebung kerucut, pelepah krem berbulu bersusuhan warna coklet kemerahan, pelepah resusun berseling berhadapan, rapat dengan ${ }_{2}$ ujung membuka; Perakaran luas $28 \mathrm{~m}$; tipe simpodial; akar udara muncul hingga buku ke -10. Kanopi membulat. Ruas batang, panjang $\times$ diameter $=19,5 \mathrm{~cm}$ $34 \mathrm{~cm} \times 7,6 \mathrm{~cm}-8,2 \mathrm{~cm}$; warna hijau muda; bersusuhan krem tebal tersebar merata. Buku-buku batang, panjang $\times$ diameter $=$ $2 \mathrm{~cm} \times 8,4 \mathrm{~cm}-11,8 \mathrm{~cm}$; memiliki 2 cincin putih di atas dan di bawah buku batang. Pelepah batang segitiga sama kaki memanjang, tinggi $\times$ alas $=38,5 \mathrm{~cm}$ $40,2 \mathrm{~cm} \times 28,3 \mathrm{~cm}-43,5 \mathrm{~cm}$; mudah luruh; sisi luar beralur, bersusuhan krem, berbulu balig halus hitam, menggimbal sangat halus putih tersebar dari bagian pangkal sampai ujung; sisi dalam beralur, bersusuhan, krem tebal di bagian basal dan ujung, berbulu balig halus hitam tersebar merata; lidah bergigi, tinggi lidah pelepah $=0,3-1 \mathrm{~cm}$. 

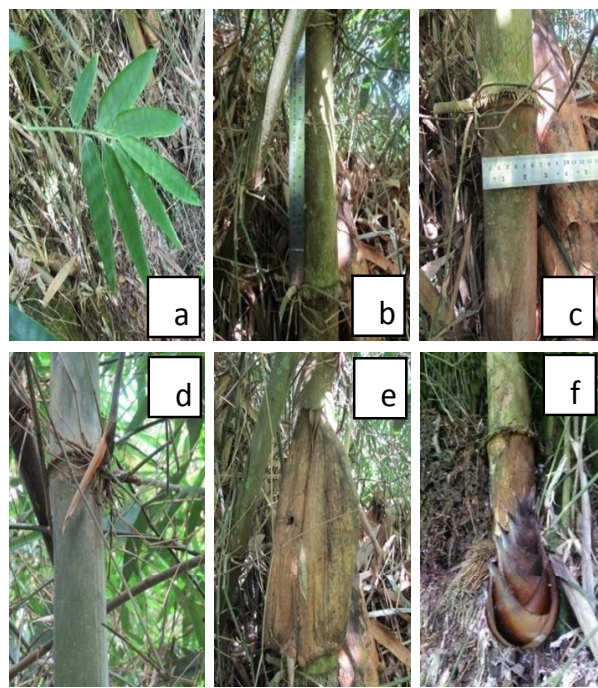

Gambar 2. Dendrocalamus sp., keterangan: (a). daun, (b). batang, (c). buku batang, (d). percabangan, (e). pelepah batang, (f). rebung.

Daun pelepah batang jorong, tinggi $\times$ alas $=18,5 \mathrm{~cm}-20,5 \mathrm{~cm} \times 4,7 \mathrm{~cm}-5 \mathrm{~cm}$; terlekuk balik; sisi luar beralur, bersusuhan krem di bagian basal; sisi dalam beralur, bersusuhan kream tebal di bagian basal sampai tengah. Percabangan 2 cabang dominan (two dominant branches at node), jumlah cabang mencapai 3-18/ buku batang, percabangan mulai dari buku ke 2-3 pada ketinggian $70 \mathrm{~cm}-120 \mathrm{~cm}$. Pelepah daun melonjong, tinggi $\times$ alas $=9-10,4$ $\mathrm{cm} \times 1-1,5 \mathrm{~cm}$; sisi luar beralur, gundul, berbulu balig halus coklat di bagian ujung; sisi dalam beralur, gundul, licin mengkilat; margo mengutuh; telinga pelepah appendik gundul.

Tangkai daun berbulu balig halus putih jarang, panjang $=0,6-0,7 \mathrm{~cm}$. Helaian daun melonjong, panjang $\times$ lebar $=$ $10 \mathrm{~cm}-30,3 \mathrm{~cm} \times 2 \mathrm{~cm}-5 \mathrm{~cm}$, hijau tua; daun abaksial beralur gundul, daun adaksial beralur, gundul, pertulangan daun menonjol ke arah adaksial; jumlah tulang daun (vena) 7 - 9 helai; pangkal daun tidak semetri; ujung daun menjarum; pinggiran daun menggergaji.

Distribusi: Lombok Timur, Montong Gading, desa Perian, dusun Srijata, sungai Trengwillis TNGR. Nama lokal: Tereng Petung (Sasak Srijata). Habitat: tumbuh di tanah lempung berpasir, pada tebing sungai, suhu $25^{\circ} \mathrm{C}$ $31^{\circ} \mathrm{C}$, kelembaban $50 \%-52 \%$, ketinggian 634m-635m dpl.

\section{Gigantochloa sp.}

Arah pertumbuhan rebung searah jarum jam, rebung kerucut memanjang, pelepah krem, tersusun spiral, cukup rapat, berbulu bersusuhan krem; daun pelepah jorong memanjang. Perakaran, luas $4,8 \mathrm{~m}^{2}$; tipe simpodial, tidak memiliki akar udara. Kanopi membulat. Ruas batang panjang $\times$ diameter $=39 \mathrm{~cm} \times$ $6,1 \mathrm{~cm}$, hijau $(7,5 \mathrm{GY} 7 / 10)$; bersusuhan coklat kehitaman merata di bawah; Bukubuku batang panjang $\times$ diameter $=$ $1 \mathrm{~cm} \times 6,3 \mathrm{~cm}$; memiliki dua cincin putih di atas dan di bawah buku batang. Pelepah batang segitiga sama kaki melebar, tinggi $\times$ alas $=26 \mathrm{~cm} \times 24,5 \mathrm{~cm}$; mudah luruh; sisi luar beralur, bersusuhan coklat bagian bawah sisi kanan pelepah batang sisi kiri hitam lebat merata bersusuhan pirang; sisi dalam beralur, gundul, licin mengkilat; pinggiran mengutuh; lidah mengutuh, tinggi lidah $=0,2 \mathrm{~cm}$. Daun pelepah batang menjorong, tinggi $\times$ alas $=8,7 \mathrm{~cm} \times 3,2 \mathrm{~cm}$; terlekuk balik; sisi luar beralur sejajar, menggimbal krem di bagian basal, berambut hitam panjang $5,7 \mathrm{~cm}$ berjumlah 18 helai di bagian sisi kanan daun pelepah batang; sisi dalam beralur, berambut hitam panjang $7 \mathrm{~cm}$ berjumlah 8 helai; pinggiran mengutuh, Percabangan satu cabang dominan (one dominant branches at node), jumlah cabang mencapai 9-1 1/ buku-buku batang. Percabangan muncul dari buku ke-3 pada ketinggian $39 \mathrm{~cm}$. Pelepah daun melonjong, tinggi $\times$ alas $=8,6 \mathrm{~cm} \times$ $0,8 \mathrm{~cm}$; sisi luar beralur, gundul; sisi dalam beralur, gundul, licin mengkilat; pinggiran berkelijak (ciliate) - memisai (hirsute) krem di ujung pelepah sebelah kanan; telinga membulat gundul; lidah mengutuh. 


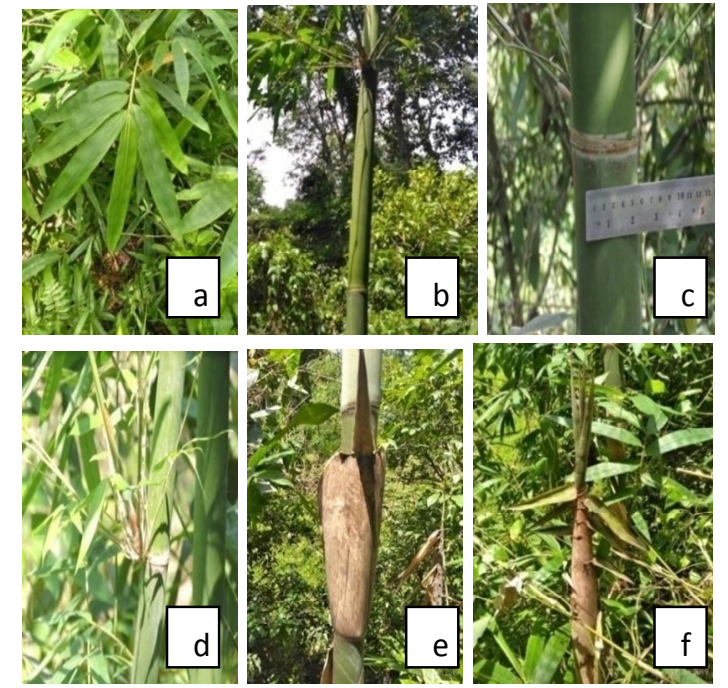

Gambar 3. Gigantochloa sp. (a). daun, (b). batang, (c). buku batang, (d). percabangan, (e). pelepah batang, (f). rebung.

Tangkai daun beralur, gundul, panjang $=$ $0,7 \mathrm{~cm}$. Helaian daun melonjong, panjang $\times$ lebar $=7 \mathrm{~cm}-25 \mathrm{~cm} \times 1,3 \mathrm{~cm}-2,5 \mathrm{~cm}$; hijau; daun abaksial beralur, kasap putih; daun adaksial beralur, kasap putih, pertulangan daun menonjol ke arah adaksial; jumlah tulang daun (vena) 5 helai; pangkal daun tidak simetri; ujung daun menjarum; pinggiran daun menggeregaji.

Distribusi: Lombok Timur, Montong Gading, desa Perian, dusun Srijata, sungai Trengwilis TNGR. Nama lokal: Tereng Galah (Sasak Srijata). Habitat: tumbuh di tanah berpasir, pada tebing sungai, suhu $31^{\circ} \mathrm{C}$, kelembaban $52 \%$, ketinggian $644 \mathrm{~m} \mathrm{dpl}$.

\section{Gigantochloa apus (Schult.) Kurz:}

Natuurk. Tijdschr. Ned. - Indië 27: 2261864.

Arah pertumbuhan rebung searah jarum jam. Perakaran luas $2,37 \mathrm{~m}^{2}$; tipe simpodial; tidak memiliki akar udara. Kanopi membulat. Ruas batang panjang $\times$ diameter $=42 \mathrm{~cm} \times 6,30 \mathrm{~cm}$; hijau $(2,5 \mathrm{G} 4 / 6)$; beralur, bersusuhan coklat sampai hitam di bagian batang. Bukubuku batang, panjang $\times$ diameter $=1 \mathrm{~cm} \times$ 6,6 cm; memiliki dua cincin putih dan coklat di atas buku batang. Pelepah batang mendelta, tinggi $\times$ alas $=15,7 \mathrm{~cm}-$ $27 \mathrm{~cm} \times 18,5 \mathrm{~cm}-28,9 \mathrm{~cm}$; tidak mudah luruh; sisi luar beralur, bersusuhan coklat tua membentuk garis sejajar dan totol hitam; sisi dalam beralur, gundul, licin mengkilat; pinggiran mengutuh menjenggot, coklat di ujung bagian kiri; ligah bergigi tinggi lidah $=0,3 \mathrm{~cm}-0,5 \mathrm{~cm}$.
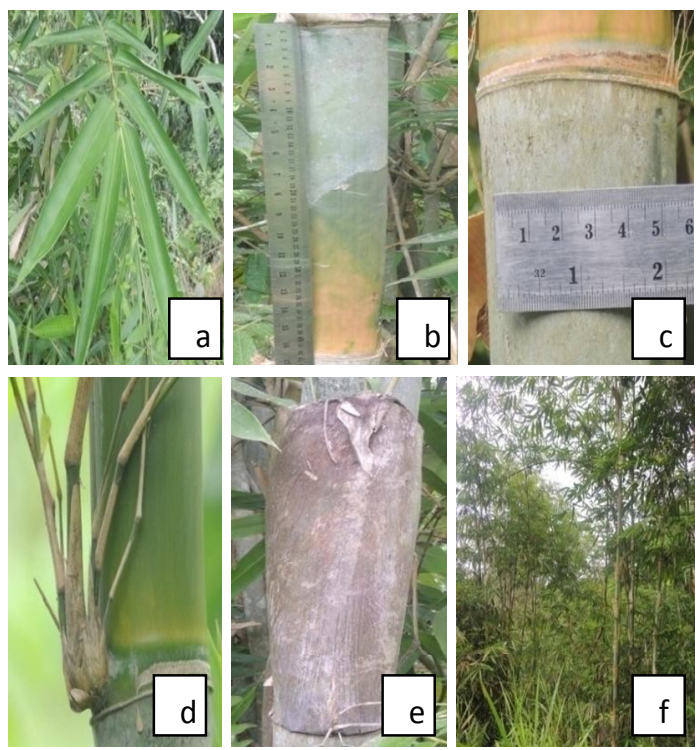

Gambar 4. G. apus (a). daun, (b). batang, (c). buku batang, (d). percabangan, (e). pelepah batang, (f). rumpun.

Daun pelepah batang bulat telur terlekuk balik; sisi luar beralur, bersusuhan coklat tua; sisi dalam beralur, menggimbal hitam tebal di bagian basal; pinggiran menggerregaji; lidah membulat gundul. Percabangan satu cabang dominan (one branches at node), jumlah cabang mencapai 6-20/ buku batang, percabangan mulai dari buku ke-2 pada ketinggian $47 \mathrm{~cm}$. Pelepah daun melonjong, tinggi $\times$ alas $=4,7 \mathrm{~cm}-2,1 \mathrm{~cm}$ $\times 1 \mathrm{~cm}-1,3 \mathrm{~cm}$; sisi luar beralur, berbulu balig halus putih di bagian tengah; sisi dalam beralur, gundul, licin mengkilat; pinggiran mengutuh kecuali di tengah memisai krem; telinga membulat gundul; lidah mengutuh. Tangkai daun beralur, gundul, panjang $=0,5 \mathrm{~cm}-1 \mathrm{~cm}$. Helaian daun melonjong, panjang $\times 1 \mathrm{ebar}=11 \mathrm{~cm}$ $37 \mathrm{~cm} \times 2,4 \mathrm{~cm}-7,4 \mathrm{~cm} ;$ hijau tua $(2,5 \mathrm{G} 4 / 6)$; daun abaksial beralur, kasap 
putih merata pertulangan daun menonjol ke arah abaksial; daun adaksial beralur,

gundul, kasap putih di bagian midrib; jumlah tulang lateral (vena) 5 - 8 helai; pangkal daun tidak simetris; ujung daun menjarum; pinggiran daun menggeregaji.

Distribusi: Lombok Timur Kecamatan Montong Gading, desa Perian, dusun Taer-aer, sungai Trengwilis TNGR. Nama lokal: Tereng Tali (Sasak Taer-aer). Habitat: tumbuh di tanah berpasir, pada tebing sungai, suhu $30^{\circ} \mathrm{C}$ -

$32^{\circ} \mathrm{C}$, kelembaban 58-65\%, ketinggian 641m-729m dpl.

\section{Gigantochloa atter (Hassk.) Kursz:} Natuurk. Tijdschr. Ned. - Indië 27: 2261864 1864.
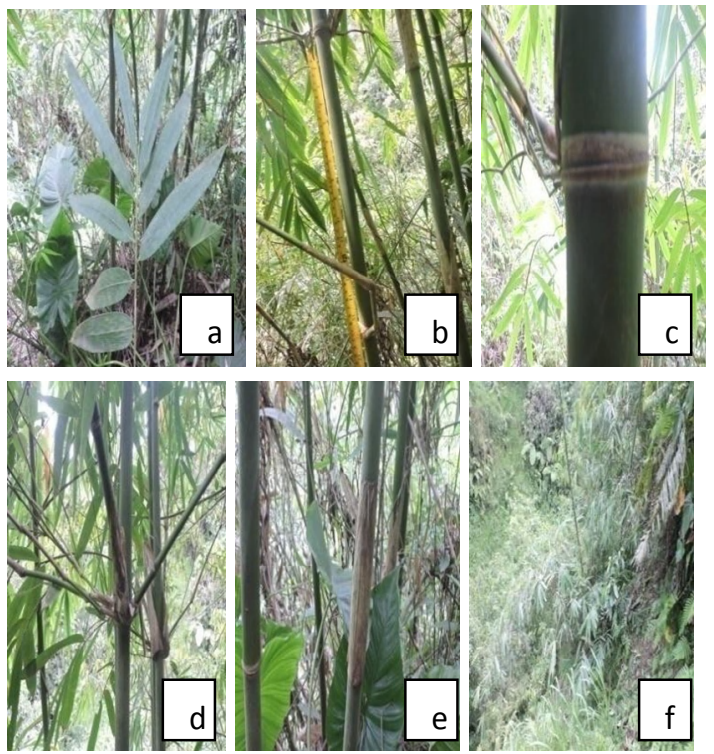

Gambar 5.
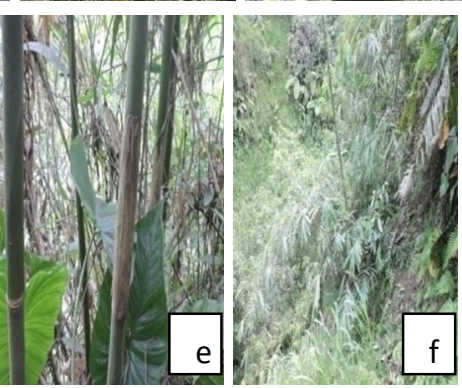

percabangan,

G. atter (a). daun,

(b). percabangan, (e). pelepah batang, (f). rumpun.

Arah pertumbuhan rebung searah jarum jam; luas perakaran 9,3 $\mathrm{m}^{2}$; tipe perakaran simpodial; tidak memiliki akar udara. Bentuk kanopi membulat. Ruas batang panjang $\times$ diameter $=30 \mathrm{~cm}-41 \mathrm{~cm}$ $\times 2,2 \mathrm{~cm}-6,7 \mathrm{~cm}$; hijau; bersusuhan krem; buku batang, panjang $\times$ diameter $=$ $0,1 \mathrm{~cm}-1,5 \mathrm{~cm} \times 2,4 \mathrm{~cm}-6,9 \mathrm{~cm}$, memiliki 2 cincin putih di atas dan di bawah buku batang, Pelepah batang segitiga sama kaki melebar, tinggi $\times$ alas $=10,6 \mathrm{~cm}-$ $23,5 \mathrm{~cm} \times 8,5 \mathrm{~cm}-31,5 \mathrm{~cm}$; mudah luruh; sisi luar beralur, bersusuhan coklat tebal merata dari bagian basal sampai ujung; sisi dalam beralur, gundul, licin mengkilat; pinggiran mengutuh; telinga appendik gundul hanya di sebelah kiri; lidah bergigi, tinggi lidah $=0,1 \mathrm{~cm}-0,7 \mathrm{~cm}$. Daun pelepah batang bulat telur, tinggi $\times$ alas $=2,5 \mathrm{~cm}-8 \mathrm{~cm} \times 1 \mathrm{~cm}-3 \mathrm{~cm}$; terlekuk balik; sisi luar beralur berbulu balig halus putih; sisi dalam beralur, menggimbal krem di bagian basal; pinggiran menggerregaji. Percabangan satu cabang dominan (one dominant branches at node), jumlah mecapai 4-20 cabang/ buku batang, percabangan mulai dari buku ke 1-4 pada ketinggian $23 \mathrm{~cm}$ $111 \mathrm{~cm}$. Pelepah daun melonjong; tinggi $\times$ alas $=4,2 \mathrm{~cm}-10,7 \mathrm{~cm} \times 0,1 \mathrm{~cm}-1,3 \mathrm{~cm}$. sisi luar beralur, memisai putih di tengah; sisi dalam beralur, gundul, mengkilat, licin; pinggiran mengutuh kecuali di ujung pelepah sebelah kanan berkelijak krem; telinga membulat gundul; lidah mengutuh. Tangkai daun beralur gundul, panjang $0,3 \mathrm{~cm}-0,7 \mathrm{~cm}$. Helaian daun melonjong, panjang $\times$ lebar $=4 \mathrm{~cm}-36 \mathrm{~cm}$ $\times 1 \mathrm{~cm}-4,8 \mathrm{~cm}$, hijau; daun abaksial beralur, kasap putih di bagian midrib; daun adaksial beralur, kasap putih di bagian midrib, pertulangan daun menonjol di bagian basal dan ujung daun; jumlah tulang lateral (vena) 6 - 9 helai; pangkal daun tidak simetri; ujung daun menjarum; pinggiran daun menggerregaji.

Distribusi: Lombok Timur, Montong Gading, desa Perian, dusun Taer-aer, sungai Trengwilis TNGR. Nama lokal: Tereng Galah (Sasak Taeraer). Habitat: tumbuh di tanah berpasir, pada tebing dan sempadan sungai, suhu $26^{\circ} \mathrm{C}-31^{\circ} \mathrm{C}$, kelembaban $52 \%-80 \%$, ketinggian $623 \mathrm{~m}-647 \mathrm{~m}$ dpl. 
6 Bambusa vulgaris Schrad.: Coll. Pl. 2: 26180.
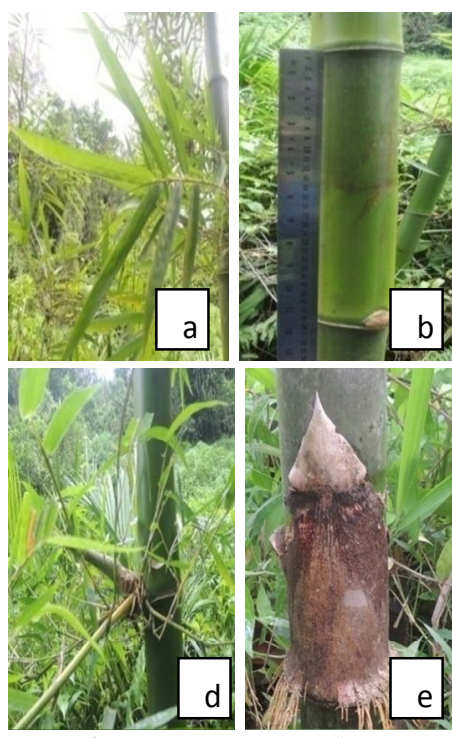

Gambar 6. B. vulgaris (a). daun, (b). batang, (c). buku batang, (d). percabangan, (e) pelepah batang, (f). rumpun.

Arah pertumbuhan rebung searah jarum jam; Perakaran luas $9,5 \mathrm{~m}^{2}$; tipe simpodial; memiliki akar udara hingga buku ke 2-3. Kanopi membulat. Ruas batang panjang $\times$ diameter $=24 \mathrm{~cm}-29 \mathrm{~cm}$ $\times 3,8 \mathrm{~cm}-5,3 \mathrm{~cm}$, hijau tua $(7,5 \mathrm{GY} 4 / 6)$; gundul, hijau mengkilat, buku batang, Panjang $\times$ diameter $=0,2 \mathrm{~cm}-1 \mathrm{~cm} \times$ 4,5cm-6,2cm; tidak memiliki cincin. Pelepah batang mendelta, tinggi $\times$ alas $=$ $9,5 \mathrm{~cm}-15,6 \mathrm{~cm} \times 6 \mathrm{~cm}-23 \mathrm{~cm} ;$ mudah luruh; sisi luar bersusuhan coklat kehitaman; sisi dalam beralur, gndul, licin mengkilat; pinggiran berkelijak coklat; lidah mengutuh, berkelijak halus coklat; tinggi lidah $=0,1 \mathrm{~cm}-0,3 \mathrm{~cm}$. Daun pelepah batang mendelta, tinggi $\times$ alas $=$ $6-7 \mathrm{~cm} \times 0,4-6 \mathrm{~cm}$; tegak; sisi luar beralur, bersusuhan coklat, berbulu balig halus hitam; sisi dalam beralur, menggimbal coklat, berbulu balig halus coklat di tengah midrib; pinggiran beronak coklat; telinga appendik, beronak krem di ujung. Percabangan 4 cabang dominan (four dominant branches at node), jumlah cabang mencapai 20/ buku-buku batang, percbangan mulai dari buku ke 3-8 pada ketinggian $60 \mathrm{~cm}-$ $186 \mathrm{~cm}$. Pelepah daun melonjong, tinggi $\times$ alas $=3,2 \mathrm{~cm}-8,2 \mathrm{~cm} \times 0,4 \mathrm{~cm}-0,8 \mathrm{~cm}$; sisi luar beralur, berbulu balig halus putih,; sisi dalam beralur, gundul, licin, mengkilat; pinggiran mengutuh; telinga appendik, memisai pirang di ujung sebelah kiri; lidah mengutuh. Tangkai daun beralur berbulu balig halus hitam, panjang $=0,2 \mathrm{~cm}-0,5 \mathrm{~cm}$. Helaian daun melonjong, panjang $\times$ lebar $=2 \mathrm{~cm}$ $20,2 \mathrm{~cm} \times 1 \mathrm{~cm}-3,2 \mathrm{~cm}$; hijau $(2,5 \mathrm{G} 5 / 10)$; daun abaksial beralur gundul, pertulangan daun menonjol di bagian abaksial kecuali di bagian midrib kasap halus; daun adaksial beralur, gundul pertulangan daun menonjol ke arah adaksial; jumlah tulang lateral (vena) $5-6$ helai; pangkal daun rata; ujung daun menduri; pinggiran daun menggeregaji.

Distribusi: Lombok Timur, Montong Gading, desa Perian dusun Taer-aer, sungai Trengwilis TNGR. Nama lokal: Tereng Dendeng (Sasak Taer-aer). Habitat: tumbuh di tanah berpasir dan becek, dasar tebing di bibir palung sungai, pada suhu $28-29^{\circ} \mathrm{C}$, kelembaban 84-89\%, ketinggian 654 683 mdpl.

\section{Schizotachyum sp.}

Arah pertumbuhan rebung searah jarum jam; Perakaran luas $5,8 \mathrm{~m}^{2}$; tipe simpodial; tidak memiliki akar udara. Kanopi membulat. Ruas batang panjang $\times$ diameter $=33 \mathrm{~cm}-35 \mathrm{~cm} \times 2,2 \mathrm{~cm}-2,9 \mathrm{~cm}$, hijau kekuningan, bersusuhan putih lebat diujung. Buku-buku batang, panjang $\times$ diameter $=1 \mathrm{~cm} \times 2,2 \mathrm{~cm}-3 \mathrm{~cm}$, memiliki 1 cincin putih di atas buku batang. Pelepah batang segitiga sama kaki, tinggi $\times$ alas $=$ $12,2 \mathrm{~cm}-14,1 \mathrm{~cm} \times 10 \mathrm{~cm}-12,1 \mathrm{~cm}$; mudah luruh; sisi luar beralur, bersusuhan coklat-pirang di bagian pinggiran, bersusuhan halus hitam tersebar merata; sisi dalam beralur, gundul, licin mengkilat; pinggiran mengutuh; telinga appendik gundul di sebelah kiri; lidah 
mengutuh, tinggi lidah $=0,3 \mathrm{~cm}-0,4 \mathrm{~cm}$. Daun pelepah batang bulat telur, tinggi $x$ alas $=3 \mathrm{~cm}-5,2 \mathrm{~cm} \times 1,4 \mathrm{~cm}-2,8 \mathrm{~cm}$, terlekuk balik; sisi luar beralur, berbulu balig halus krem; sisi dalam beralur, menggimbal krem di bagian basal; Pinggiran menggeregaji. Percabangan sama besar (subequel branches in row above nodal line), jumlah mencapai 8 cabang/ buku-buku batang, percabangan mulai dari buku ke-3 pada ketinggian $35 \mathrm{~cm}-70 \mathrm{~cm}$. Pelepah daun melonjong, tinggi $\times$ alas $=6,3 \mathrm{~cm}-12,3 \mathrm{~cm} \times 0,5 \mathrm{~cm}-$ $1,2 \mathrm{~cm}$; sisi luar beralur, bersusuhan coklat, menyutera putih di bagian tengah marginal; sisi dalam beralur, gundul, licin mengkilat; pinggiran memisai krem; telinga membulat gundul; lidah berkelijak krem. Tangkai daun beralur; kasap putih, panjang $=0,5 \mathrm{~cm}-1 \mathrm{~cm}$.
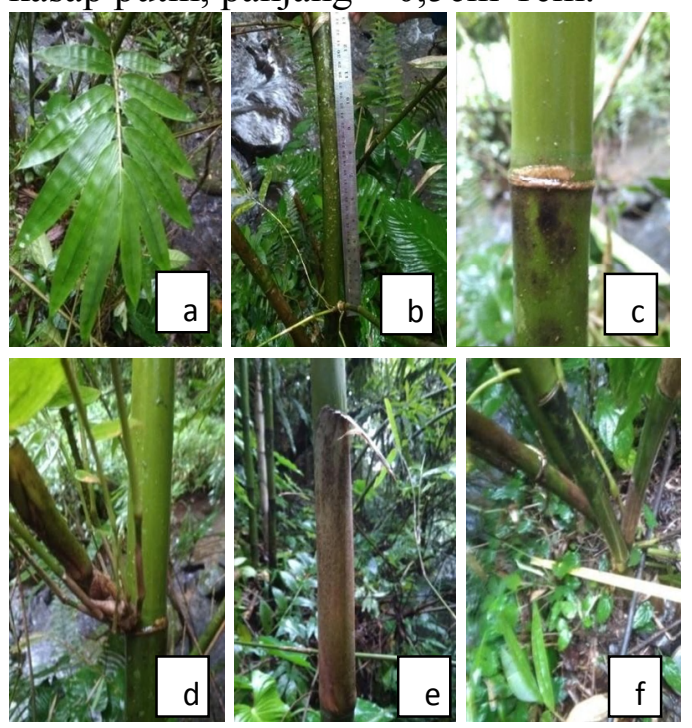

Gambar 8. Schizotachyum sp. (a). daun, (b). ruas batang, (c). buku batang, (d). percabangan, (e). pelepah batang, (f). perakaran.

Helaian daun melonjong, panjang $\times$ lebar $=7,4 \mathrm{~cm}-36,2 \mathrm{~cm} \times 2 \mathrm{~cm}-5 \mathrm{~cm} ;$ hijau $(2,5 \mathrm{G} 5 / 10)$ daun abaksial beralur, kasap putih, di bagian basal, daun adaksial beralur, kasap putih di bagian margin, pertulangan daun menonjol ke arah adaksial; helai; pangkal tidak simetris; ujung menjarum; pinggiran menggeregaji. Jumlah tulang daun $6-11$
Distribusi: Lombok Timur, Montong Gading, desa Perian dusun Srijata, sungai Trengwilis TNGR. Nama lokal: Tereng Willis (Sasak Srijata). Habitat: tumbuh di tanah berpasir dan becek, pada tebing sungai, suhu $26{ }^{\circ} \mathrm{C}$ $32^{\circ} \mathrm{C}$; kelembaban $60 \%-76 \%$, ketinggian 659m-661m dpl.

\section{Peta Persebaran Keanekaragaman Jenis Bambu di Sempadan Sungai Trengwillis Resort Joben Taman Nasional Gunung Rinjani Lombok.}

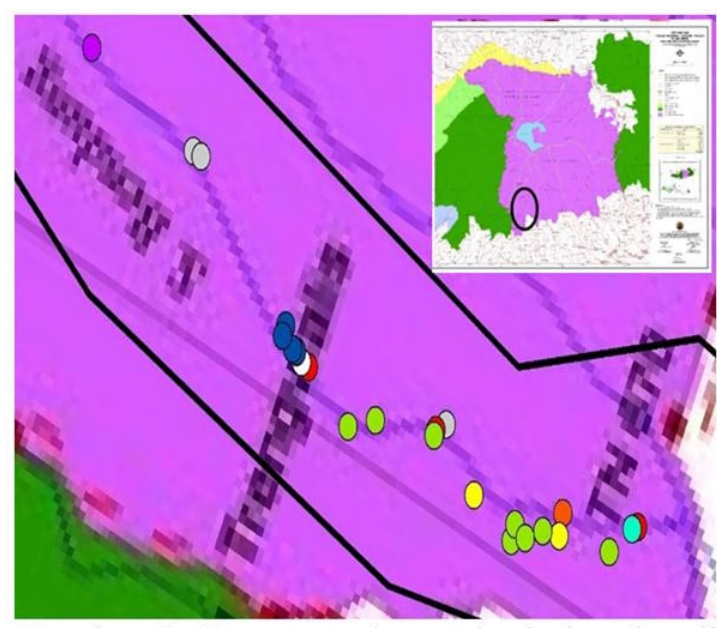

Gambar 9. Peta persebaran jenis bambu di sempadan sungai Trengwilis Resort Joben Taman Nasional Gunung Rinjani Lombok, keterangan: $\bigcirc D$. asper, OGigantochloa $\mathrm{sp}$. ODendrocalamus sp. O Dinochloa sp. O Schizostachyum sp, O Bambusa vulgaris, ○ Giagantochloa apus, O Gigantochloa atter, o batas yang dapat dijangkau.

Pada Gambar 9, dapat dilihat pola persebaran jenis-jenis bambu di sempadan sungai Trengwilis sepanjang $2,5 \mathrm{~km}$ yang terjangkau dalam pengambilan sampel, pada ketinggian antara 623m-729m dpl., ditemukan marga Dendrocalamus yang tumbuh pada ketinggian $631 \mathrm{~m}-644 \mathrm{~m}$ dpl, marga Bambusa (631m-652m dpl), marga Schizotachyum (661m-659m dpl), dan yang paling banyak ditemukan di sempadan sungai Trengwilis tempat 
lokasi penelitian adalah marga Gigantochloa pada ketinggian tempat $623 \mathrm{~m}-729 \mathrm{~m} \mathrm{dpl}$

Jenis bambu yang ditemukan dan mampu tumbuh di daerah aliran sungai, terutama pada bibir sungai/ pinggiran palung sungai atau dasar tebing sungai adalah $B$. vulgaris dan yang tumbuh pada tebing sungai adalah $D$. asper, Dendrocalamus sp. Gigantochloa sp., sedangkan yang tumbuh di tebing maupun di sempadan sungai adalah $G$. apus, G. atter.

Diantara bambu yang diketemukan dilihat dari tipe perakaran dan bentuk kanopinya hanya terdapat satu tipe, yaitu tipe perakaran sympodial dan bentuk kanopi yang membola, terdapat pada bambu jenis: B. vulgaris, D. asper, Dendrocalamus sp. Gigantochloa sp. G. apus, G. atter dan Schizotachyum sp. Mayasari dan Suryawan, 2012 menyatakan bahwa bambu yang memiliki sistem perakaran simpodial dapat mencegah terjadinya erosi, tanah longsor dan banjir, penanaman bambu pada lahan kritis dapat menjadi daya dukung lingkungan. Bambu yang memiliki bentuk kanopi membulat sangat baik untuk konservasi tanah dan air karena memiliki permukaan daun yang berlapislapis sehingga mampu menjaga limpasan air dengan baik. Menurut Sofiah \& Fiqa, 2011, tanaman bambu dibandingkan tanaman kluih lebih baik dalam mengkonservasi tanah dan air karena bambu membentuk akar serabut sehingga mampu menyimpan dan menyerap air lebih banyak di dalam tanah, bentuk tajuk yang rapat dan helaian daun sempit mampu mengurangi cucuran air hujan yang jatuh secara lansung sehingga tidak akan memukul permukaan tanah.

\section{KESIMPULAN}

Berdasarkan hasil penelitian yang telah dilakukan dapat disimpulkan bahwa didapatkan tujuh jenis bambu yang termasuk ke dalam lima genus di sempadan sungai Trengwilis Resort Joben Taman Nasional Gunung Rinjani Lombok yaitu B. vulgaris, D. asper, Dendrocalamus sp. Gigantochloa sp. G. apus, G. atter dan Schizotachyum sp. Empat jenis bambu yang ditemukan yaitu Dendrocalamus sp. Schizotachyum sp Gigantochloa sp. Bambu yang tumbuh pada ketinggian 600-an mdpl yaitu dari jenis $\quad B$. vulgaris, $D$. asper, Dendrocalamus sp. Gigantochloa sp. G. atter dan Schizotachyum sp. Bambu yang ditemukan tumbuh di ketinggian $623 \mathrm{~m}$ $729 \mathrm{~m}$ dpl adalah G. apus.

\section{UCAPAN TERIMA KASIH}

Penulis pada kesempatan ini ingin mengucapkan terima kasih kepada bapak Dr. Ir. R. Agus Budi Santoso, M.Si. selaku kepala Balai Taman Nasional Gunung Rinjani Lombok yang telah memberikan izin dan mefasilitasi dalam penelitian bambu di sempadan sungai Trengwillis kawasan Taman Nasional Gunung Rinjani (TNGR), Lombok. Selanjutnya ucapan terima kasih juga penulis tujukan kepada Bapak Karti, Hadianto, Haji Purna Irawan dan Hirman zohri selaku staf TNGR. Lombok.

\section{DAFTAR PUSTAKA}

Ariyana, I.G.K. (2014). Studi populasi Dinochloa sepang, bambu endemik Bali. Buletin Kebun Raya 17 (1): 3544.

Bagus, I. K. A., (2005). Keanekaragaman dan Penggunaan Jenis-Jenis Bambu Di Desa Tigawasa, Bali. UPT Balai Konservasi Tumbuhan Kebun Raya "Eka Karya” UPT Bali-LIPI.

Clark, L.G., X. Londono \& E. RuizSanchez. (2015). Bamboo Taxonomy and Habitat. In Liese. W \& M. Kohl (eds.) Bamboo, Tropical Forestry 10. 
Springer International Publishing Switzerland. DOI 10.1007/978-3319-14133-6_1

Cundaningsih N., Rima, S.S., Arosyani, E., Amalia, A., Irawan, B., (2015). Kajian Ekologi Bambu Hitam Bahan Baku Angklung di Jawa Barat. Departemen Biologi, Fakultas Matematika dan Ilmu Pengetahuan Alam, Universitas Padjadjaran.

Damayanto, I.P.G.P. (2017). Climbing bamboos of Lesser Sunda Islands, Indonesia. Proceedia "The $1^{\text {st }}$ SATREPS Conference" Bogor. Pp. 90-93

Damayanto, I.P.G.P., S. Mulyani \& Bq. F. Wahidah. (2019). Inventarisasi, kunci identifikasi, pemetaan, dan rekomendasi pengelolaan jenis-jenis bambu di ecology park, pusat Konservasi tumbuhan, kebun rayaLIPI, Kabupaten Bogor, Jawa Barat. JURNAL ARSITEKTUR LANSEKAP 5 (1): 114-124.

Erviyanti, D., E.A. Widjaja \& A. Sedayuet. (2019). Bamboo diversity of Sulawesi, Indonesia. Biodiversitas 20 (1): 91-109.

Dieter. (2018). Bamboos of thailand $\mathrm{http}: / /$ sites.google.com/site/bamboost hailand/home/-1-nativespecies/bambusa-bambos

Hanafi, H.R., B. Irawan, D. C. Pertiwi \& A. Litania. (2017). Pemanfaatan dan pengelolaan bambu berkelanjutan di Desa Cijedil, Cianjur, Jawa Barat sebagai upaya perwujudan Sustainable Development Goals (SDGs). Pros. Sem. Nas. Masy. Biodiv. Indon. 3 (2): 230-235.

Octriviana, R.,Ainnurasjid \&N.R Ardini. (2017). Observasi plasma nutfah bambu di kabupaten Malang. Jurnal Produksi Tanaman 5 (6): 1044-1052.

Huzaemah., Mulyaningsih, T., Aryanti, E., (2016), Identifikasi Bambu di Daerah Aliran Sungai Tiupupus Kabupaten Lombok Utara, Jurnal Biologi Tropis, Vol. 16 (2): 23-36.

Mayasari. A. dan A. Suryawan, (2012). Keragaman Jenis Bambu Dan Pemanfaatannya Di Taman Nasional Alas Purwo. Balai Penelitian Kehutanan Manado. Info BPK Manado 2(2): 139-154.

Mentari, M., T. Mulyaningsih \& E. Aryanti. (2018). Identifikasi bambu di sub Daerah Aliran Sungai Kedome Kab Lombok Timur dan Alternatif manfaat untuk konservasi sempadan sungai. Jurnal Penelitian Pengelolaan Daerah Aliran Sungai 2 (2): 111-122. Doi http://dx.doi.org/10.20886/jppdas.201 8.2.2.111-122.

Munawarah, A., (2016), Iventarisasi Bambu Di Daerah Aliran Sungai Semoya Lombok Barat, [Skripsi], Program Studi Bioogi, Fakultas Matematika Dan Ilmu Pengetahuan Alam, Universitas Mataram. Mataram.

Peneng, I. N., I. N. Pedas dan I, N. R. Suteja. (2005). Eksplorasi Bambu di Kabupaten Lombok Tengah Nusa Tenggara Barat, Laporan tehnik program perlindungan dan konservasi konservasi sumber daya alam kebun Raya "Eka Karya", Denpasar.

Putri, R. J. P., T. Mulyaningsih, E. Aryanti. (2016). Kekayaan Jenis Bambu Di Daerah Aliran Sungai Jangkok Di Pulau Lombok Nusa Tenggara Barat. Laporan Akhir 
Penelitin DIPA BLU (PNBP). Universitas Mataram.

Rijaya, I. \& Fitmawati. (2019). Jenisjenis bambu 9Bambusoideae) di pulau Bengkalis Provinsi Riau, Indonesia. Floribunda 6 (2): 40-52.

Simpson, M. G. (2006). Plant Systematics. Elsevier Academic Press. New York.

Sofiah, S., dan A. P. Fiqa., (2011). Karakterisasi Tumbuhan Lokal untuk Konservasi Tanah dan Air, Studi Kasus pada Kluwih (Artocarpus altilis (Park ex Zoll.) Forsberg) dan Bambu Hitam (Gigantochloa atroviolaceae Widjaja). Berkala Penelitian HAYATI, Edisi Khusus, 29-32.

Sulisistyowati, S.E., D. Ervianti, M.A.R. Marmy, R.F. Andriani \& R. Fauziah. (2014). Kecepatan laju reproduksi vegetatif berbagai jenis bambu di PPKA bodogol, Taman Nasional Gunung Gede Pangrango. Bioma 10 (2): $24-27$.

Wijaya, E.A. \& Wiyono. (2005). Keanekaragaman bambu di pulau Sumba. Biodiversitas 6 (2): 95-99. 